\title{
Immunological methods to study monoclonal antibody activity in Chronic Lymphocytic
}

\section{Leukaemia}

MJ Carter ${ }^{1 \$}$, LN Dahal $^{1 \$}$, KLS Cleary ${ }^{1 \$}$, MJE Marshall $^{1 \$}$, RR French $^{1}$, SA Beers ${ }^{1}$, MS Cragg $^{1}$

${ }^{1}$ Antibody \& Vaccine Group, Cancer Sciences Unit, Faculty of Medicine, University of Southampton, Southampton General Hospital, Southampton SO16 6YD, UK

${ }^{\$}$ These authors contributed equally

Running Head: Immunological Methods to Study CLL

\begin{abstract}
Over recent decades it has become increasingly apparent that malignant cells, including chronic lymphocytic leukemia (CLL) cells, do not exist in isolation. Rather they coalesce with numerous "normal" cells of the body and, in the case of CLL, inhabit key immunological niches within secondary lymphoid organs (SLO), where a plethora of stromal and immune cells mediate their growth and survival. With the advent and approval of targeted immune therapies such as monoclonal antibodies (mAb), which elicit their efficacy by engaging immune-mediated effector mechanisms, it is important to develop accurate methods to measure their activities. Here we describe a series of reliable assays capable of measuring important antibody-mediated effector functions: antibody dependent cellular phagocytosis (ADCP), antibody dependent cellular cytotoxicity (ADCC), and complement dependent cytotoxicity (CDC) that measure these immune activities.
\end{abstract}

Key Words secondary lymphoid organs (SLO); monoclonal antibodies (mAb); antibody dependent cellular phagocytosis (ADCP); antibody dependent cellular cytotoxicity (ADCC); complement dependent cytotoxicity (CDC) 
Immunotherapeutic approaches have revolutionised the treatment of haematological malignancies [1]. These new therapeutic agents are predominantly monoclonal antibodies $(\mathrm{mAb})$ and engage the immune system to unleash powerful immune-mediated effector mechanisms, resulting in the destruction of the malignant cell. Classically, this has been achieved by direct opsonisation of the malignant cell. In the case of CLL and related B-cell cancers, the CD20 pan-B cell marker was targeted, resulting in the rise of therapeutics such as rituximab (RTX) [2-4]. These "direct-targeting" therapeutics engage both complement- and cell-mediated effector mechanisms, resulting in cellular destruction [5]. Despite this advance, RTX is rarely curative and merely functions to delay disease progression. In recent years, resistance mechanisms that limit the efficacy of RTX, and other directtargeting mAbs, have become apparent [6-8]. These observations have resulted in a renewed effort to develop novel approaches to solve this problem. Such approaches include generation of more active glyco-engineered direct-targeting mAbs, such as obinutuzumab, co-administration of additional mAbs (e.g. anti-Fc $\gamma$ RIIB) that overcome specific resistance mechanisms, and the identification and development of mAb to novel targets [9-13]. In order to assess the impact of these approaches, assays are required to examine the relative efficacy of each of these mAb-mediated effector mechanisms.

Here we describe a series of robust, reproducible assays that are capable of assessing antibodydependent phagocytosis (ADCP), antibody-dependent cellular cytotoxicity (ADCC) and complementdependent cytoxicity (CDC).

\section{$2 \quad$ Materials}

1. Anonymised leukocyte blood cone or whole blood from a healthy volunteer [Note 1]

2. Heparin Sodium $1000 \mathrm{IU} / \mathrm{ml}$

3. Complete RPMI: RPMI, $10 \%$ heat inactivated foetal calf serum (FCS), $2 \mathrm{mM}$ glutamine, $1 \mathrm{mM}$ pyruvate, 45 units $/ \mathrm{ml}$ penicillin, $45 \mu \mathrm{g} / \mathrm{ml}$ streptomycin

4. Serum free RPMI: RPMI, $2 \mathrm{mM}$ glutamine, $1 \mathrm{mM}$ pyruvate, 45 units $/ \mathrm{ml}$ penicillin, $45 \mu \mathrm{g} / \mathrm{ml}$ streptomycin 
5. 1\% HS RPMI: RPMI, $1 \%$ Human Serum, $2 \mathrm{mM}$ glutamine, $1 \mathrm{mM}$ pyruvate, 45 units $/ \mathrm{ml}$ penicillin, $45 \mu \mathrm{g} / \mathrm{ml}$ streptomycin

6. Phosphate buffered saline (PBS), 2mM ethylenediaminetetraacetic acid (EDTA)

7. PBS (2mM EDTA, $10 \%$ FCS $)$

8. Density gradient medium (Lymphoprep)

9. $\quad$ PBS, $1 \%$ bovine serum albumin (BSA), $0.1 \% \mathrm{NaN}_{3}$ )

10. Carboxyfluorescein succinimidyl ester (CFSE) $5 \mathrm{mM}$ in DMSO

11. Macrophage colony stimulating factor (M-CSF)

12. APC labelled anti-human CD16

13. Murine macrophage medium: RPMI, 10\% FCS, $2 \mathrm{mM}$ glutamine, $1 \mathrm{mM}$ pyruvate, 45 units $/ \mathrm{ml}$ penicillin, $45 \mu \mathrm{g} / \mathrm{ml}$ streptomycin, $50 \mu \mathrm{M} \beta$-mercaptoethanol, 20\% L929 culture supernatant

14. Calcein Acetoxymethyl (Calcein AM)

15. Triton-X100 (TX-100)

16. CLL cells. Taken from ethically approved tissue bank. Fresh cells may also be used

\section{$3 \quad$ Methods}

\subsection{Human monocyte derived macrophage phagocytosis}

This assay relies on the ability of macrophages to engulf opsonised (antibody coated) target cells (CLL cells in this case). Target cells are first labelled with the fluorescent dye CFSE and then opsonised with the antibody of interest before co-culture with macrophages. Macrophages are subsequently labelled with a specific marker (anti-CD16 APC) and phagocytic macrophages are quantitated as $\mathrm{CD}_{16}{ }^{+} \mathrm{CFSE}^{+}$events (Figure 1).

\subsubsection{Purification of human peripheral blood mononuclear cells (PBMC)}

1. Decant blood into $50 \mathrm{ml}$ tube and top up with PBS (2mM EDTA, $10 \%$ FCS).

2. Overlay $12.5 \mathrm{ml}$ room temperature (RT) density gradient medium (Lymphoprep) [Note 2] with $25 \mathrm{ml}$ blood, and centrifuge at $800 \mathrm{xg}$ for 20 minutes at RT with the brake off. 
3. Remove interphase layer, containing peripheral blood mononuclear cells (PBMCs) into a $50 \mathrm{ml}$ tube and wash by re-suspending the PBMCs in $50 \mathrm{ml}$ PBS (2mM EDTA), followed by centrifugation at $300 \mathrm{xg}$ for 5 minutes at $4^{\circ} \mathrm{C}$. Repeat wash step an additional 3 times.

\subsubsection{Adherent Cell Selection}

1. Re-suspend pellet to $1 \times 10^{7}$ cells $/ \mathrm{ml}$ in $1 \% \mathrm{HS}$ RPMI and pipette $2 \mathrm{ml}$ of cells per well in a 6 well plate and incubate for 2 hours at $37^{\circ} \mathrm{C}, 5 \% \mathrm{CO}_{2}$ to allow cells to adhere.

2. Gently agitate the plate and assess cellular adhesion by light microscopy [Note 3]. Remove nonadherent cells by gently swirling the media around the well using a disposable plastic pipette and remove medium. Wash wells by adding 2-3 $\mathrm{ml}$ PBS per well followed by agitation and removal of added PBS. Repeat as necessary, checking cells under microscope for effective removal of non-adherent cells. Add $2 \mathrm{ml}$ complete RPMI per well and incubate overnight at $37^{\circ} \mathrm{C}, 5 \% \mathrm{CO}_{2}$ (Day 0).

\subsubsection{Macrophage Differentiation}

1. Add $100 \mathrm{ng} / \mathrm{ml} \mathrm{M-CSF}$ on day 1 . [Note 4]

2. Remove $850 \mu \mathrm{l}$ medium from each well and replenish with $1 \mathrm{ml}$ complete RPMI (+100ng/ml MCSF) on day 3 and 5.

3. After 1 week remove media and wash wells with PBS. To harvest, add $2 \mathrm{ml} /$ well ice cold PBS and incubate on ice for 15 minutes.

4. Dislodge adherent cells by using a cell scraper and collect in a centrifuge tube. Wash cells in PBS by centrifugation at 300xg for 5 minutes. Re-suspend in complete RPMI and adjust cell concentration to $5 \times 10^{5}$ cells $/ \mathrm{ml}$. Plate macrophages in a 96 well plate at $1 \times 10^{5}$ cells $/$ well [Note 5]. Incubate for 4 hours at $37^{\circ} \mathrm{C}, 5 \% \mathrm{CO}_{2}$. ADCP assays should be concluded within 4-6 hours following plating.

\subsubsection{Target Cell Preparation}

1. Take CLL PBMCs (defrost if required) and re-suspend at $2 \times 10^{7}$ cells $/ \mathrm{ml}$ in serum free RPMI. [Note 6] 
2. Dilute stock CFSE to a working concentration $(0.5 \mathrm{mM})$ in PBS. Rapidly mix $10 \mu \mathrm{CFSE}$ working stock with $1 \mathrm{ml}$ of target cell suspension [Note 7] and incubate for 10 minutes in the dark at RT.

3. Add equal volume of FCS and incubate for 1 minute to quench labelling. Wash labelled cells by adding excess complete RPMI followed by centrifugation at 300xg for 5 minutes at RT. Perform 2 further washes in complete RPMI.

4. Re-suspend labelled cells at $2.5 \times 10^{6}$ cells $/ \mathrm{ml}$ in complete RPMI. Divide target cells into experimental conditions (i.e. no $\mathrm{mAb}$, isotype control $\mathrm{mAb}$, and $\mathrm{mAb}$ of interest). Add opsonising antibody (at appropriate concentration) to relevant wells and incubate for 30 minutes at $4^{\circ} \mathrm{C}$ in the dark. Rituximab is an effective positive control in this assay.

5. Following opsonisation, wash cells in complete RPMI by centrifugation at 300xg for 5 minutes. Re-suspend opsonised cells at $2.5 \times 10^{6}$ cells $/ \mathrm{ml}$ in complete RPMI.

\subsubsection{ADCP Assay}

1. Remove media from macrophages.

2. Add $100 \mu 1$ opsonised target cells (giving a 5:1 target: effector ratio) to the macrophages and incubate at $37^{\circ} \mathrm{C}, 5 \% \mathrm{CO}_{2}$ for 1 hour [Note 5].

3. Add $10 \mu \mathrm{g} / \mathrm{ml}$ anti-human CD16 APC antibody and incubate for 15 minutes in the dark at RT.

4. Remove media and wash wells by adding and subsequently discarding $200 \mu \mathrm{l}$ R PBS (1\% BSA, $0.1 \% \mathrm{NaN}_{3}$ ) [Note 8] Add $200 \mu \mathrm{l}$ ice cold PBS and incubate on ice for at least 10 minutes.

5. Dislodge cells from well by scraping with pipette tip and place into flow cytometry tube as quickly as possible (maximum assay time is 4-6 hours). Analyse cells by flow cytometry, collecting at least $2000 \mathrm{CD} 6^{+}$cells per tube. Assess $\mathrm{CD} 16^{+}$cells for CFSE positivity (See Figure 1 for example)

\subsubsection{Murine Bone Marrow Derived Macrophages Differentiation}

Alternatively, this assay can be conducted using murine bone marrow derived macrophages as effectors. 
1. Sacrifice mouse. Dissect mouse hind legs (femur/tibia).

2. Remove all tissue from the bones being careful not to crush the bone in order to reduce contamination from other cells.

3. Cut off each end of bone and using a $0.5 \times 16 \mathrm{~mm}$ needle and $10 \mathrm{ml}$ syringe containing media, flush bone marrow into a $50 \mathrm{ml}$ tube.

4. Pass bone marrow suspension through $100 \mu \mathrm{m}$ cell strainer into a petri dish, homogenise with the stopper from a sterile $2 \mathrm{ml}$ syringe and wash through a cell strainer into a $50 \mathrm{ml}$ tube using a disposable plastic pipette to obtain a single cell suspension.

5. Wash cell suspension by centrifugation at $300 \mathrm{xg}$ for 5 minutes and discard supernatant.

6. Re-suspend final cell pellet in $5 \mathrm{ml}$ murine macrophage media and perform cell count [Note 9].

7. Re-suspend at $1 \times 10^{6}$ cells $/ \mathrm{ml}$ Plate $5 \mathrm{ml} /$ well in 6 -well plates and culture at $37^{\circ} \mathrm{C}, 5 \% \mathrm{CO}_{2}$ for 7 10 days before use.

8. Feed every $2-3$ days by removing all the media from the wells and replenishing with $5 \mathrm{ml}$ fresh murine macrophage media [Note 9].

\subsection{Antibody-dependent cellular cytotoxicity (ADCC) assay}

This assay relies on the ability of NK cells to kill and lyse opsonised target cells (CLL cells in this case). Target cells are first labelled with the fluorescent dye calcein-AM, washed and then opsonised with the antibody of interest before co-culture with PBMCs (including NK cells). Cell-lysis is detected by the presence of fluorescent calcein released into the media (Figure 2).

1. Purify PBMCs from whole blood or anonymised blood cone by density gradient centrifugation as outlined in section 3.1 .

2. Re-suspend PBMC pellet at $4 \times 10^{7}$ cells $/ \mathrm{ml}$ in complete $\mathrm{RPMI}$ and incubate at $37^{\circ} \mathrm{C}, 5 \% \mathrm{CO}_{2}$ until commencement of the assay.

3. Obtain CLL PBMC sample (defrost if necessary [Note 6] and re-suspend at $1 \times 10^{7}$ cells $/ \mathrm{ml}$ in complete RPMI. Add calcein AM to the cells so that a final concentration of $10 \mu \mathrm{g} / \mathrm{ml}$ is reached (Note 7). Incubate at $37^{\circ} \mathrm{C}, 5 \% \mathrm{CO}_{2}$ for 30 minutes with periodic agitation. 
4. Wash cells by addition of excess PBS (2mM EDTA, 10\% FCS) followed by centrifugation at $400 \times \mathrm{xg}$ for 5 minutes at RT. Perform an additional 2 washes. Re-suspend cell pellet at $1.6 \times 10^{6}$ cells $/ \mathrm{ml}$ in complete RPMI and plate $0.8 \times 10^{5}$ cells $(50 \mu \mathrm{l})$ per well in 96 well round-bottom plates.

5. Divide target cells into experimental conditions (i.e. no $\mathrm{mAb}$, isotype control $\mathrm{mAb}$, and $\mathrm{mAb}$ of interest) and add opsonising antibody to the relevant wells at the required concentration (for example a range from $10 \mu \mathrm{g} / \mathrm{ml}$ in five-fold dilutions) in $50 \mu \mathrm{l}$ to target cells and incubate for 30 minutes at $4^{\circ} \mathrm{C}$. Rituximab is an effective positive control in this assay.

6. Add $100 \mu \mathrm{l}$ of PBMCs (at $4 \times 10^{7} / \mathrm{ml}$ ) to give a 50:1 effector: target ratio and briefly pulse-spin the centrifuge plate at $400 \mathrm{xg}$ for 10 seconds to bring cells into contact. Incubate at $37^{\circ} \mathrm{C}, 5 \%$ $\mathrm{CO}_{2}$ for 4 hours. To record the maximum possible calcein release, add $100 \mu 1$ of $4 \%$ TritonX100 (diluted in complete RPMI) to calcein labelled (but non-opsonised) target cells.

7. Centrifuge plate at $400 \mathrm{xg}$ for 5 minutes at RT to pellet cells. Transfer $85 \mu \mathrm{l}$ of supernatant per well to a white 96-well flat-bottom plate and read calcein release on a fluorescent plate reader. Calcein is excited at $485 \mathrm{~nm}$ and is detected at $530 \mathrm{~nm}$.

8. The fluorescence units taken from the plate reader are converted into the percentage of maximum lysis use the following equation:

$$
\% \text { Maximal Lysis }=((\text { Sample }- \text { No mAb }) /(T X-100-\text { No } m A b)) * 100
$$

\subsection{Complement-dependent cytotoxicity (CDC) assay}

This assay relies on the ability of complement to lyse opsonised target cells (CLL cells in this case). Cells are opsonised with the antibody of interest before addition of serum (containing complement). Cell-lysis is assessed by the ability of a viability dye (PI) to enter the cell and detected by flow cytometry (Figure 3 ).

\subsubsection{Human Serum collection}

CDC assays require the use of human serum which can either be freshly obtained or stored for short periods of time at $-80^{\circ} \mathrm{C}$ in glassware. Commercially available serum has, in our hands, a reduced 
capacity to evoke complement-mediated killing and, therefore, is not recommended. Collect a $40 \mathrm{ml}$ blood sample from a healthy volunteer into an appropriate glass tube, stir with a wooden stick, and allow to clot for $30-60$ minutes at RT. Centrifuge at $900 \mathrm{xg}$ at $4^{\circ} \mathrm{C}$ for 20 minutes. Remove serum, being careful not to disturb the pellet. If not using immediately, aliquot serum into appropriate glass tubes $\left(1-2 \mathrm{ml}\right.$ capacity) for single assay use and store at $-80^{\circ} \mathrm{C}$. Prior to use, thaw rapidly in a $37^{\circ} \mathrm{C}$ water bath and do not re-freeze.

\subsubsection{CDC Assay}

Isolate CLL PBMC target cells by density gradient centrifugation, as outlined in section 3.1

1. Re-suspend target cells at $1 \times 10^{6}$ cells $/ \mathrm{ml}$ in complete RPMI. Plate cells in a 96-well plate $(100 \mu \mathrm{l}$ per well).

2. Opsonise cells by addition of experimental mAbs (i.e. no treatment, isotype control $\mathrm{mAb}, \mathrm{mAb}$ of interest) at required concentration (a serial dilution from $10 \mu \mathrm{g} / \mathrm{ml}$ is recommended) in a sufficient volume of complete RPMI to give a final reaction volume of $200 \mu$. CAMPATH-1H (alemtuzumab) is an effective positive control in this assay. Incubate at RT for 15 minutes.

3. Thaw human serum aliquot and dilute 1:1 (vol/vol) in serum free RPMI. Add to each well to give a final concentration of $10-30 \%$ human serum (see [Note 10] for serum concentrations). Incubate at $37^{\circ} \mathrm{C}, 5 \% \mathrm{CO}_{2}$ for 30 minutes. After the incubation keep plate on ice to prevent further complement activity from occurring.

4. Harvest cells by pipetting and transfer to flow cytometry tube. Add $50 \mu \mathrm{lof} 10 \mu \mathrm{g} / \mathrm{ml}$ propidium iodide (PI) (dissolved in PBS) to each tube immediately prior to acquisition on the flow cytometer.

5. As illustrated in Figure 3a, gate out serum contaminants and debris events that are low in the FSC/SSC axis and then measure the percentage of cell death by the proportion of cells which are $\mathrm{PI}^{+}$. 
1. Leukocyte cones are a waste product of platelet donation containing cellular constituents of blood and plasma, and are available from blood transfusion centres

2. When overlaying cells onto density gradient medium, tilt the tube and utilise a pipette controller set at the lowest setting to minimise disturbance of the interface.

3. Non-adherent cells accumulate at the centre of the plate following 2 hours incubation. Dislodge the non-adherent cells by gently tapping/agitating the plate.

4. M-CSF allows differentiation of monocytes into macrophages

5. The aim is to have $5 \times 10^{4}$ effector cells (macrophages) co-cultured with $2.5 \times 10^{5}$ target cells (CLL) to achieve a ratio of 1:5 effector: target cell ratio. We routinely lose macrophages during subsequent washing steps. In order to account for the loss during washing steps, plate twice the number of macrophages (i.e. $1 \times 10^{5}$ per well) at this stage.

6. Pre-warm serum free RPMI media in an incubator at $37^{\circ} \mathrm{C}$. Add $1-2 \mathrm{ml}$ of warm media to frozen cell stock, gently pipette a few times and place the cells into a $30 \mathrm{ml}$ centrifuge tube and top up with serum free RPMI. Centrifuge at 300xg for 5 minutes. Discard supernatant.

7. Do not add CFSE or calcein-AM directly to the cell suspension. Pipette it onto the wall of the tube and swirl the cell suspension to mix with the dye. Gently rotate the tube a few times.

8. Do not wash the whole plate at the first instance. Wash a few wells first and observe under the microscope to ensure the washing is not too harsh or gentle.

9. Murine macrophage media containing $20 \%$ L929 conditioned medium and $50 \mu \mathrm{M} \beta$ mercaptoethanol should be freshly prepared. L929 cells secrete M-CSF, and bone marrow monocyte/macrophage progenitors grown in the presence of L929-conditioned medium differentiate into a homogenous population of mature macrophages. Conditioned media is removed from $\mathrm{L} 929$, filtered through a $0.2 \mu \mathrm{m}$ filter, and stored at $-20^{\circ} \mathrm{C}$ prior to use.

10. Each cell type has different levels of resistance towards non-specific complement lysis, therefore we recommend testing a titration of serum concentrations to refine the assay dependent upon the 
target cell being used. We find that a final concentration of serum between $10-30 \%$ is suitable for most lymphoma cell-lines and primary CLL samples.

Acknowledgements: The authors would like to thank and acknowledge all members of the Antibody and Vaccine group, past and present, who together have helped develop these protocols and provide antibody for the studies reported. The work was supported by CRUK grants C1477/A10834, C1477/A20537, C34999/A18087 and C328/A25139; Bloodwise grant 12050 and KKLF grant KKL981

\section{References}

1. Glennie MJ, Johnson PWM (2000) Clinical trials of antibody therapy. Immunology Today 21 (8):403-410. doi:10.1016/s0167-5699(00)01669-8

2. Lim SH, Beers SA, French RR, Johnson PWM, Glennie MJ, Cragg MS (2010) Anti-CD20 monoclonal antibodies: historical and future perspectives. Haematologica-the Hematology Journal 95 (1):135143. doi:10.3324/haematol.2008.001628

3. Coiffier B, Lepage E, Briere J, Herbrecht R, Tilly H, Bouabdallah R, Morel P, Van den Neste E, Salles G, Gaulard P, Reyes F, Gisselbrecht C (2002) CHOP chemotherapy plus rituximab compared with CHOP alone in elderly patients with diffuse large-B-cell lymphoma. New England Journal of Medicine 346 (4):235-242. doi:10.1056/NEJMoa011795

4. McLaughlin P, Grillo-Lopez AJ, Link BK, Levy R, Czuczman MS, Williams ME, Heyman MR, BenceBruckler I, White CA, Cabanillas F, Jain V, Ho AD, Lister J, Wey K, Shen D, Dallaire BK (1998) Rituximab chimeric Anti-CD20 monoclonal antibody therapy for relapsed indolent lymphoma: Half of patients respond to a four-dose treatment program. Journal of Clinical Oncology 16 (8):2825-2833. doi:10.1200/jco.1998.16.8.2825

5. Glennie MJ, French RR, Cragg MS, Taylor RP (2007) Mechanisms of killing by anti-CD20 monoclonal antibodies. Mol Immunol 44 (16):3823-3837

6. Williams EL, Tutt AL, Beers SA, French RR, Chan CHT, Cox KL, Roghanian A, Penfold CA, Butts CL, Boross P, Verbeek JS, Cragg MS, Glennie MJ (2013) Immunotherapy Targeting Inhibitory Fc gamma Receptor IIB (CD32b) in the Mouse Is Limited by Monoclonal Antibody Consumption and Receptor Internalization. Journal of Immunology 191 (8):4130-4140. doi:10.4049/jimmunol.1301430

7. Lim SH, Vaughan AT, Ashton-Key M, Williams EL, Dixon SV, Chan HTC, Beers SA, French RR, Cox KL, Davies AJ, Potter KN, Mockridge Cl, Oscier DG, Johnson PWM, Cragg MS, Glennie MJ (2011) Fc gamma receptor Ilb on target $\mathrm{B}$ cells promotes rituximab internalization and reduces clinical efficacy. Blood 118 (9):2530-2540. doi:10.1182/blood-2011-01-330357

8. Clynes RA, Towers TL, Presta LG, Ravetch JV (2000) Inhibitory Fc receptors modulate in vivo cytoxicity against tumor targets. Nature Medicine 6 (4):443-446

9. Roghanian A, Teige I, Mårtensson L, Cox KL, Kovacek M, Ljungars A, Mattson J, Sundberg A, Vaughan AT, Shah V, Smyth NR, Sheth B, Chan HTC, Li Z-C, Williams EL, Manfredi G, Oldham RJ, Mockridge $\mathrm{Cl}$, James SA, Dahal LN, Hussain K, Nilsson B, Verbeek JS, Juliusson G, Hansson M, Jerkeman M, Johnson PWM, Davies A, Beers SA, Glennie MJ, Frendéus B, Cragg MS (2015) Antagonistic FcyRIIB antibodies have anti-tumor activity and overcome resistance to antibody therapy in vivo. vol 27. Cancer Cell 
10. Alduaij W, Ivanov A, Honeychurch J, Cheadle EJ, Potluri S, Lim SH, Shimada K, Chan CHT, Tutt A, Beers SA, Glennie MJ, Cragg MS, Illidge TM (2011) Novel type II anti-CD20 monoclonal antibody (GA101) evokes homotypic adhesion and actin-dependent, lysosome-mediated cell death in B-cell malignancies. Blood 117 (17):4519-4529. doi:10.1182/blood-2010-07-296913

11. Mossner E, Brunker P, Moser S, Puntener U, Schmidt C, Herter S, Grau R, Gerdes C, Nopora A, van Puijenbroek E, Ferrara C, Sondermann P, Jager C, Strein P, Fertig G, Friess T, Schull C, Bauer $S$, Dal Porto J, Del Nagro C, Dabbagh K, Dyer MJS, Poppema S, Klein C, Umana P (2010) Increasing the efficacy of CD20 antibody therapy through the engineering of a new type II anti-CD20 antibody with enhanced direct and immune effector cell-mediated B-cell cytotoxicity. Blood 115 (22):4393-4402. doi:10.1182/blood-2009-06-225979

12. Chao MP, Alizadeh AA, Tang C, Myklebust JH, Varghese B, Gill S, Jan M, Cha AC, Chan CK, Tan BT, Park CY, Zhao FF, Kohrt HE, Malumbres R, Briones J, Gascoyne RD, Lossos IS, Levy R, Weissman IL, Majeti R (2010) Anti-CD47 Antibody Synergizes with Rituximab to Promote Phagocytosis and Eradicate Non-Hodgkin Lymphoma. Cell 142 (5):699-713. doi:10.1016/j.cell.2010.07.044

13. Turaj AH, Hussain K, Cox KL, Rose-Zerilli MJJ, Testa J, Dahal LN, Chan HTC, James S, Field VL, Carter MJ, Kim HJ, West JJ, Thomas LJ, He L-Z, Keler T, Johnson PWM, Al-Shamkhani A, Thirdborough SM, Beers SA, Cragg MS, Glennie MJ, Lim SH (2017) Antibody Tumor Targeting Is Enhanced by CD27 Agonists through Myeloid Recruitment. Cancer Cell 32 (6):777-791.e776.

doi:https://doi.org/10.1016/j.ccell.2017.11.001 


\section{Figures \& Figure Legends}

A

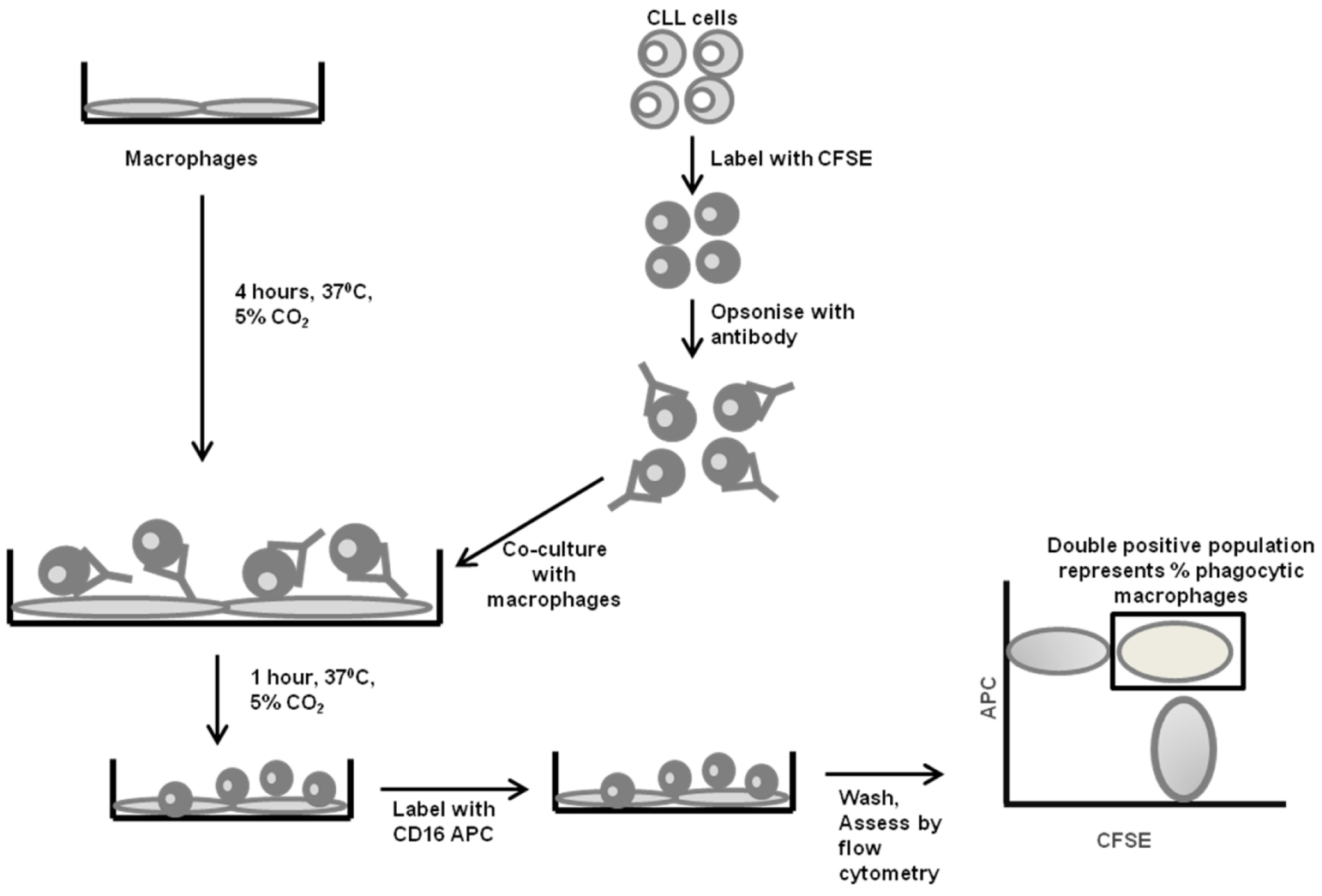

B
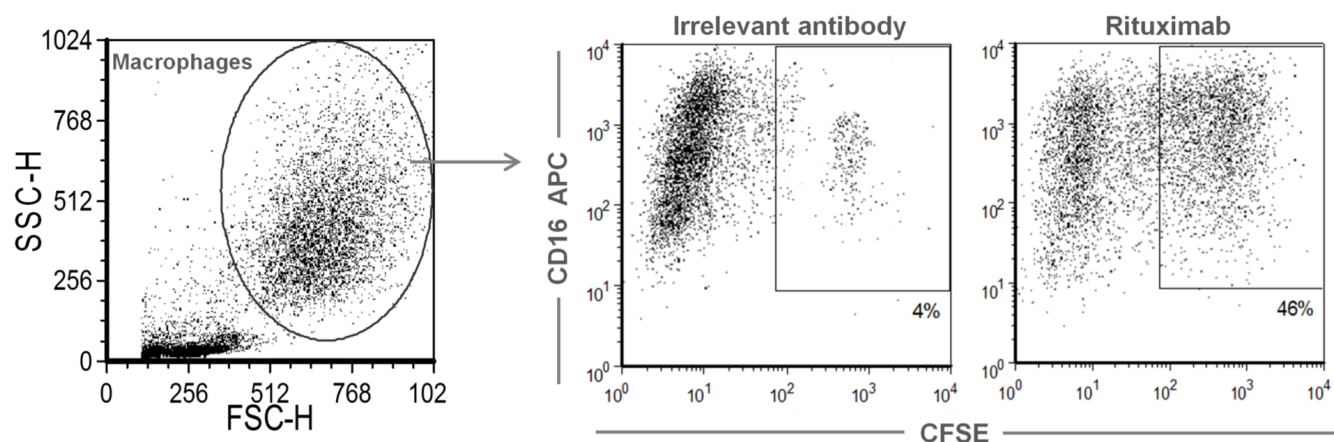

Figure 1: ADCP Assay A) Schema of antibody dependent cellular phagocytosis (ADCP) assay as described in section 3.1. B) Dot plots from flow cytometric analysis of macrophages co-cultured with CFSE labelled target CLL cells that were opsonised with an irrelevant antibody or the anti-CD20 antibody Rituximab. Numbers indicate percentage of phagocytic macrophages. 
A

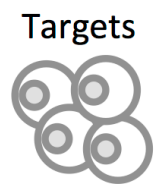

$\downarrow \begin{aligned} & \text { Label with } \\ & \text { calcein-AM }\end{aligned}$

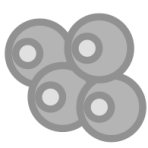

$\downarrow \begin{aligned} & \text { Label with } \\ & \text { Antibody }\end{aligned}$ $\square$

Whole

Blood

PBMC isolated

by density

centrifugation

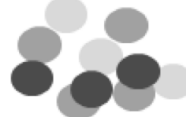

$\downarrow$

Read plate for calcein fluorescence

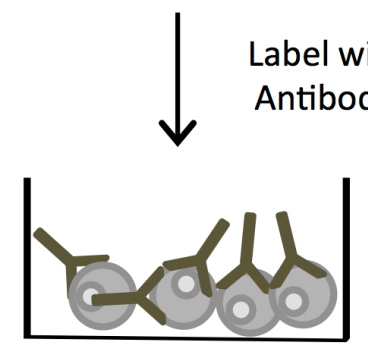

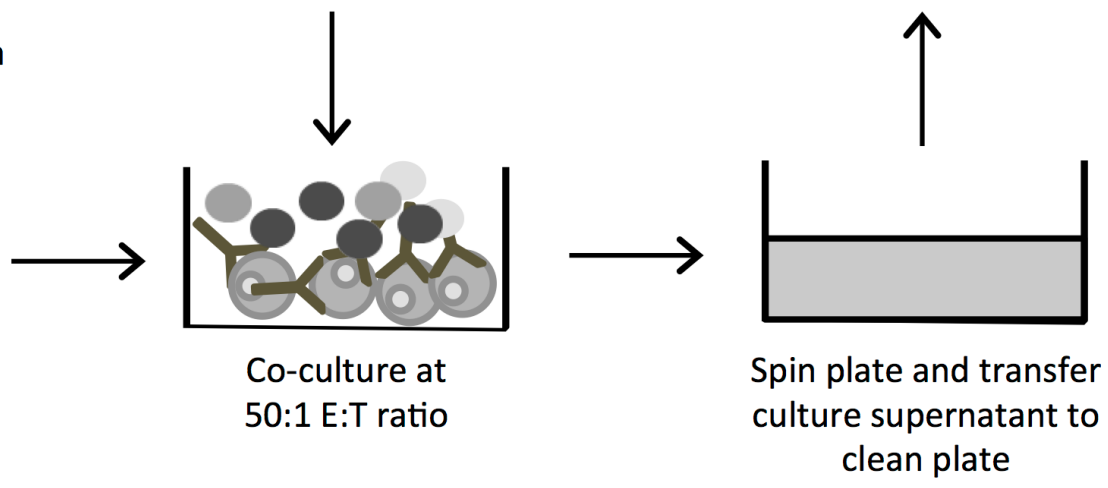

Co-culture at 50:1 E:T ratio

B

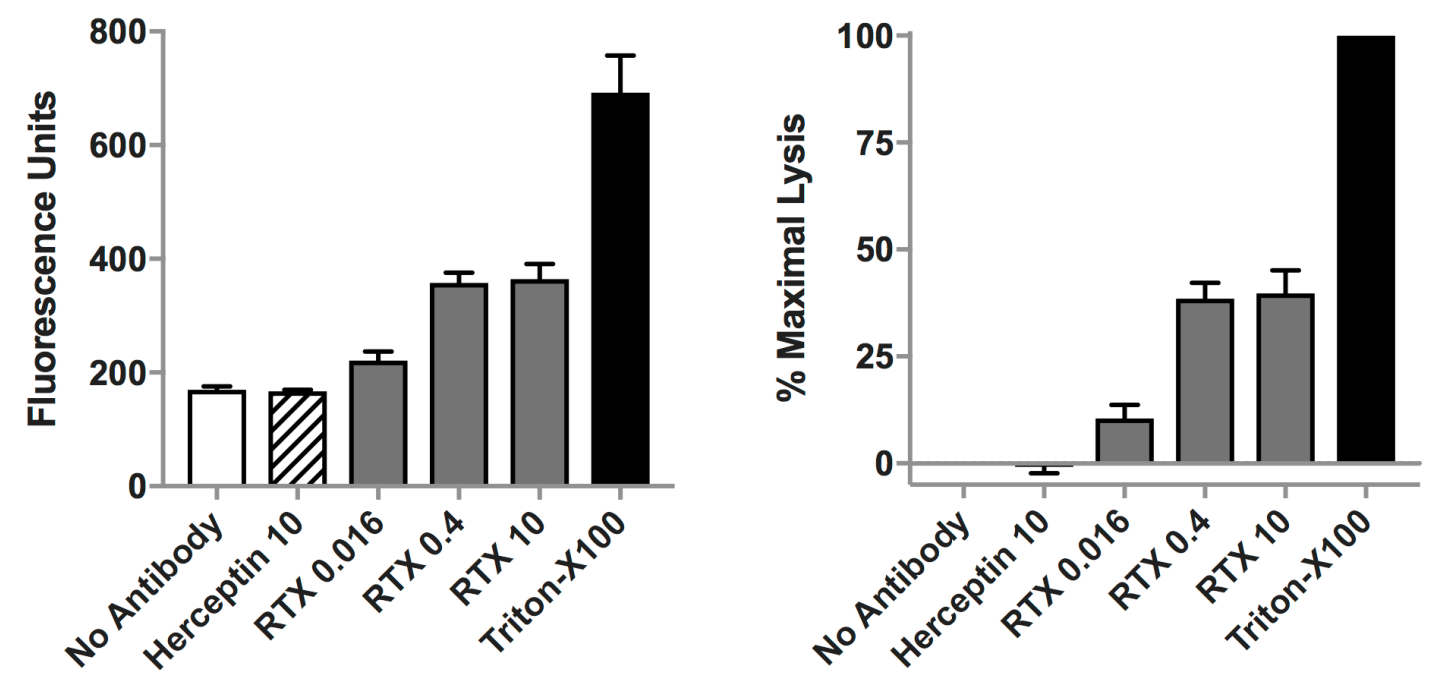

Figure 2: ADCC Assay A) Schema of ADCC as described in section 3.2. B) (Left) example raw fluorescence data of OCI-Ly1 cells treated with an isotype control mAb (Herceptin) or Rituximab (RTX). Mean and SD of triplicates plotted. Numbers denote $\mathrm{mAb}$ concentration expressed in $\mu \mathrm{g} / \mathrm{ml}$ B) (Right) Transformation of raw data from left panel as percentage of maximal lysis (determined by the Triton-X100 treated cells) using the equation described in section 3.2 
A

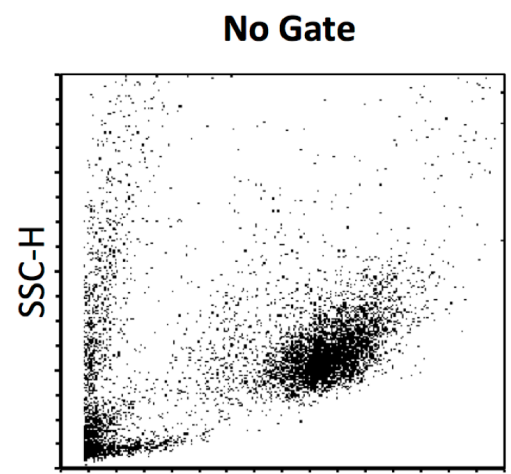

FSC-H

$10 \mu \mathrm{g} / \mathrm{ml}$ Cetuximab

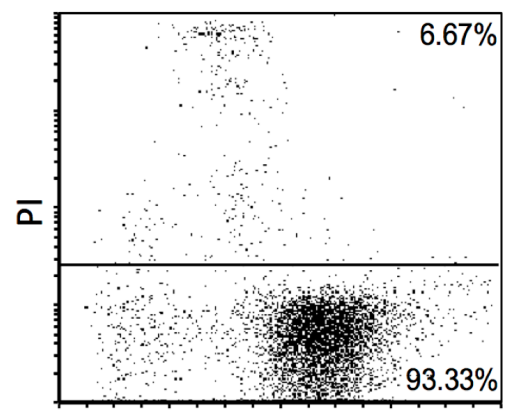

FSC-H

B

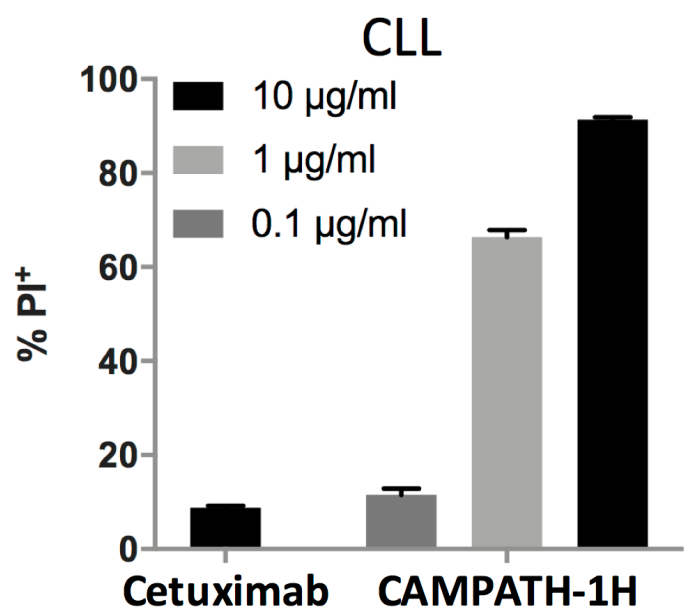

Serum Exclusion Gate

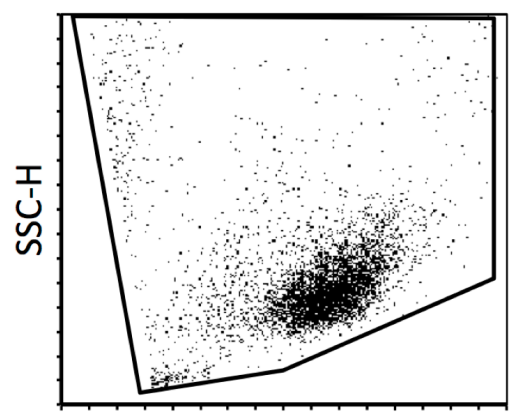

FSC-H

$10 \mu \mathrm{g} / \mathrm{ml}$ CAMPATH-1H

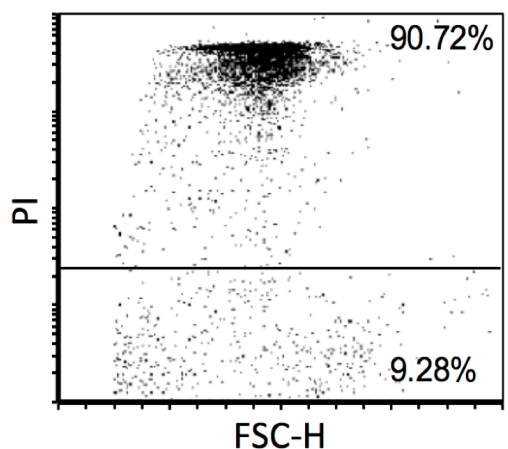

Raji

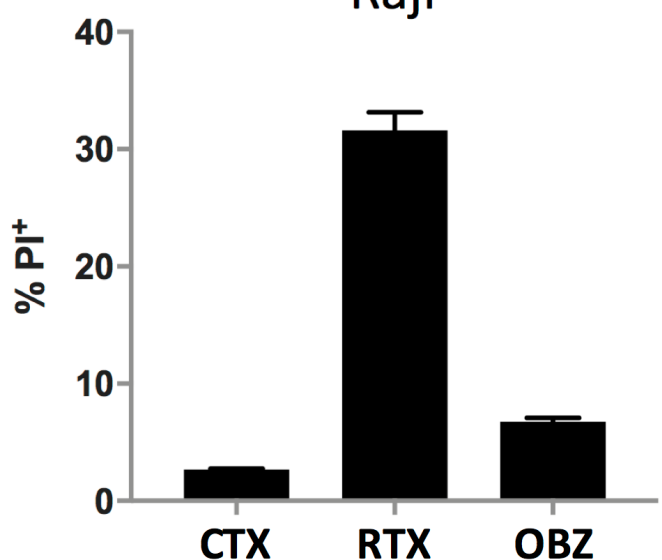

Figure 3: CDC Assay. A) Example flow cytometry dot plots for Raji cells treated with the isotype control mAb cetuximab or the anti-CD52 mAb CAMPATH-1H (alemtuzumab). B) Example data comparing percentage of $\mathrm{PI}^{+}$cells for (left) primary CLL cells treated with isotype control $\mathrm{mAb}$ cetuximab or Campath-1H and (right) Raji cells treated with isotype control mAb cetuximab (CTX), rituximab (RTX), or obinutuzumab (OBZ) at $10 \mu \mathrm{g} / \mathrm{ml}$. 